\title{
Molecular Analysis of Synedrela Nodiflora (L.) Gaertn. Resistance Against Fomesafen using Rapd Markers
}

\author{
Murni Dwiati and Agus Hery Susanto \\ Faculty of Biology Jenderal Soedirman University \\ JI. Dr. Suparno 63 Purwokerto 53122, Tel. +62-281-638794, Fax. +62-281-631700, \\ E-mail: murnidw@yahoo.co.id,
}

\begin{abstract}
Both morphological and protein studies reveal that differences are observed between resistant Synedrella nodiflora against fomesafen and its susceptible wildtype. These are, however, more or less influenced by environmental factors, so that molecular analysis employing DNA markers is necessarily required. The methods involved total genomic DNA extraction using modified CTAB protocol following Doyle \& Doyle (1990), RAPD marker amplification and visualization of RAPD markers prior to data analysis. Ten RAPD markers were used, but only seven of them showed polymorphism. Calculation of genetic distance and variation was carried out employing PopGen software.

Based on the RAPD markers used in this study, it can be concluded that genetic distance between susceptible and resistant $S$. nodiflora is higher than that within susceptible samples supporting our previous morphological and protein data, although genetic variation among susceptible individuals seems to be significantly high.
\end{abstract}

Keywords: Synedrella nodiflora, resistance, fomesafen, RAPD

\begin{abstract}
Abstrak
Studi morfologi dan penggunaan marka protein memberikan petunjuk adanya perbedaan antara Synedrella nodiflora (L.) Gaertn. yang resisten terhadap herbisida fomesafen dan tipe liarnya yang rentan terhadap herbisida tersebut. Meskipun demikian, sedikit banyak hal ini masih dipengaruhi oleh faktor lingkungan. Oleh karena itu, diperlukan analisis molekuler menggunakan marka DNA. Pada penelitian ini dilakukan ekstraksi DNA genomik total menggunakan metode CTAB yang dimodifikasi. Selanjutnya, dilakukan amplifikasi dan visualisiasi marka RAPD. Namun, dari 10 marka RAPD yang digunakan, hanya tujuh yang memperlihatkan polimorfisme. Penghitungan jarak dan variasi genetik dilakukan menggunakan piranti lunak PopGen. Hasilnya menunjukkan bahwa jarak genetik antara S. nodiflora rentan dan resisten lebih besar daripada jarak genetik di dalam populasi rentan. Hal ini mendukung hasil studi morfologi dan protein meskipun variasi genetik di antara individu rentan terlihat sangat tinggi.
\end{abstract}

Kata kunci: Synedrella nodiflora, resistensi, fomesafen, RAPD

\section{Introduction}

Synedrella nodiflora is a weed species commonly found to grow very rapidly in legume crops potentially causing serious agronomic problems. As many as 3,000 seeds ready to grow can be produced by a single plant, since they are not subject to dormancy. This eventually results in high variabilty. When these diverse plant individuals are controlled with fomesafen at a lethal dose, considerably various resistance against the herbicide will arise, and recurrent application in a long period of time may increase the resistance

Susceptible and resistant $S$. nodiflora against fomesafen show morphological differences, one of which is in terms of plant vigor. Resistant plants are larger in size in compare to that of its susceptible wildtype.
Moreover, the resistant type has also relatively better phylotaxis, which is represented by higher leaf area index. The plant is vigorous with wider and more compact leaves, indicating higher competitive capacity for survival than its susceptible wildtype, resulting in higher capacity to compete with legume crops, such as ground nut. Consequently, this reduces the yield of ground nut. Therefore, attention should be paid any time to prevent the development of resistant $S$. nodiflora in certain area, so that it is easier to manage.

The vigor of susceptible S. nodiflora varies morphologically, so that genetic differentiator among susceptible individuals is necessarily required to prevent potentially susceptible plants changing to resistant. Study on plastidal PPOase, an enzyme 
responsible for chlorophyll and heme biosynthesis, reveals that a protein band of $22.906 \mathrm{kDa}$ observed in resistant $S$. nodiflora is absent in the susceptible wildtype. So, it is assumed that this protein band can be resistance marker of $S$. nodiflora against Reflex application (Dwiati \& Susanto, 2015).

Both morphological and protein characters are, however, more or less influenced by environmental factors since they are phenotypes resulting from the interaction between genotype and environment. To provide more constant and accurate markers, molecular analysis by the use of DNA markers is necessarily required. RAPD is one of DNA markers widely used in the studies of genetic diversity in various crop species, including those in terms of plant resistance. Runtunuwu et al. (1999) reported the use of RAPD markers for coconut resistance against Phytophthora palmivora which is successfully identified by DNA polymorphism among five extremely resistant cultivars and another five extremely susceptible cultivars. Tartarini (1995) has also shown RAPD polymorphism for scab resistance among apple cultivars. Since no RAPD charac-terization for $S$. nodiflora resistance against fomesafen has been reported so far, here we are presenting RAPD profile to verify our previous morphology and protein studies.

\section{Materials and Methods}

Susceptible $S$. nodiflora wildtype seeds were obtained from Karang-wangkal Purwokerto, while the resistant types were generated by gradually increasing sublethal applications fomesa-fen on the wildtype plants for seven generations until individuals resistant to lethal dose were obtained. Fomesafen used in this study was formulated by Syngenta and known commercially as Reflex. The chemicals used included those for DNA extraction with modified CTAB protocol, PCR kit (Promega), RAPD primers (OPA7 5'- GAAACGGGTG3', OPA8 5'-GTGACGTAGG-3', OPA11 5'CAATCGCCGT- 3 ' , OPB 65 ' TGCTCTGCCC-3', OPB $75^{\prime}$ GGTGACGCAG-3', OPB 8 5' GTCCACACGG-3', OPB 10 5' CTGCTGGGAC-3') obtained from Operon Technologies (Almeda, USA) and agarose electrophoresis compo-nents. The main equipments used were minibead beater
(Biospec), genequant (General Electric), 14,000 rpm centrifuge (Thermo), thermocycler (Boeco), electrophoresis set (Biorad), UV transiluminator and digital camera.

\section{Total genomic DNA extraction}

Both fresh resistant and susceptible $S$. nodiflora leaves were weighed to $0.1 \mathrm{~g}$ and cut into small pieces before put into microtube with a bead. Then $800 \mu \mathrm{l}$ preheated CTAB in $65^{\circ} \mathrm{C}$ for 30 minutes was added, after which the leaf pieces were crushed in minibead beater for four minutes. This sample was heated in $65{ }^{\circ} \mathrm{C}$ for 60 minutes while gently mixing in every 10 minutes was conducted by inverting the tube before putting it in room tempera-ture for two minutes before $500 \mu \mathrm{l}$ chloroform isoamyl alcohol was addded. This was then vortexed for five minutes and centrifugated at 12,000 rpm for 15 minutes. Supernatant was moved cautiously into new microtube and then mixed gently with $1 / 10$ volume of $3 \mathrm{M}$ sodium acetate, after which $2 / 3$ volume of cold isopropanol was added. The mixture was kept in freezer for 24 hours before centrifugated at $12,000 \mathrm{rpm}$ for 10 minutes. Supernatant was discarded, while pellet was washed with $500 \mu \mathrm{l} 70 \%$ ethanol. The suspension was centrifu-gated at 12,000 rpm for five minutes. Supernatant was removed, while pellet was air dried before dissolved in $50 \mu \mathrm{l}$ TE buffer. The DNA solution was measured for concentration and purity using genequant and then stored at $4^{\circ} \mathrm{C}$. Once the DNA concentration was measured, alliquots of $2.5 \mathrm{ng} / \mu \mathrm{l}$ were made by diluting the solution stock (Doyle and Doyle, 1990 with modification).

\section{RAPD marker amplification and electro- phoresis}

All of the seven RAPD primers used in this study result commonly in polymorphic bands in various plant species. PCR amplification of the RAPD markers was performed in a total volume of $10 \mu$ consisting of $5 \mu \mathrm{l}$ Gotaq green, $2.25 \mu \mathrm{l} \mathrm{NFW,} 2.5 \mu \mathrm{l}$ genomic DNA as PCR template and $0.25 \mu \mathrm{l}$ primers. This PCR mixture was preheated at $95{ }^{\circ} \mathrm{C}$ for $5 \mathrm{~min}$, followed by 30 PCR cycles comprising denaturation at $95^{\circ} \mathrm{C}$ for $45 \mathrm{sec}$, annealing at $36^{\circ} \mathrm{C}$ for $1 \mathrm{~min}$ and elongation at $72{ }^{\circ} \mathrm{C}$ for $1 \mathrm{~min} 30 \mathrm{sec}$ respectively. Final elongation was conducted at $72{ }^{\circ} \mathrm{C}$ for $7 \mathrm{~min}$ 
before stored at $4{ }^{\circ} \mathrm{C}$. The PCR products were run in $1.5 \%$ gel electrophoresis gel at $75 \mathrm{~V}, 400 \mathrm{~A}$ for 40 minutes. After soaked in ethidium bromide, the gel was put on UV transiluminator and documented using digital camera. The RAPD profile was analyzed statistically using GenAlex. The visualized pattern of RAPD markers was converted into binary data $(0$ means fragment is absent and 1 means fragment is present). The calculation of genetic distance and variation was carried out employing PopGen software.

\section{Results and Discussion}

Resistant S. nodiflora leaves are found significantly larger than those of susceptible

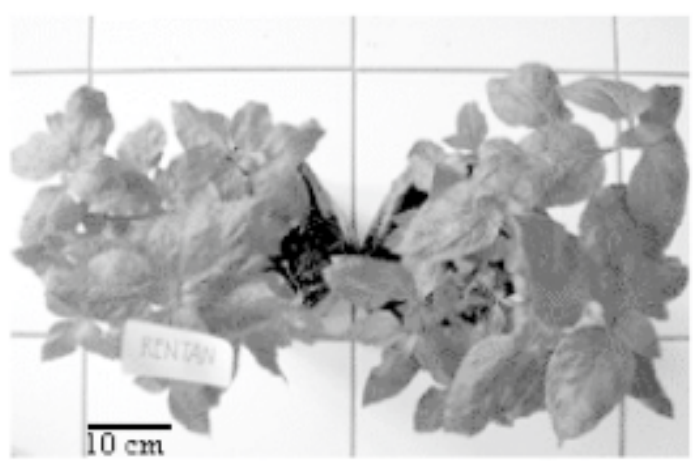

A individuals. The resistant leaves are $8.76 \pm$ $0.69 \mathrm{~cm}$ in length and $5.33 \pm 0.44 \mathrm{~cm}$ in width, while the susceptible ones are $7.76 \pm 0.34$ $\mathrm{cm}$ in length and $5.05 \pm 0.30 \mathrm{~cm}$ in width.

In addition to size, the positioning of resistant leaves seems likely to be better than that of susceptible ones, which is represented by relatively larger leaf area index. More vigorous plant with more ideal leaf positioning is also observed (Table 1), indicating that resistant $S$. nodiflora compete better for survival in compare to the susceptible wild type (Fig $1 \mathrm{~A}$ and 1B). Nevertheless, leaf thickness of resistant individuals is less than that of susceptible ones.

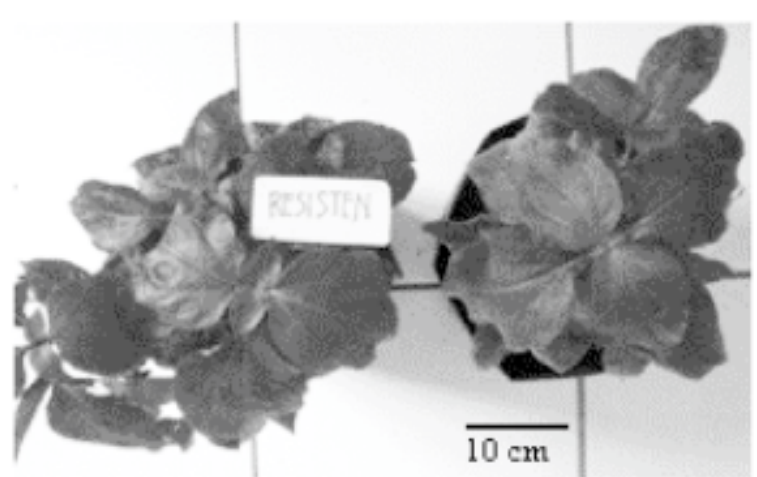

B

Figure 1. Performance of 7 week-old weed S. Nodiflora. A. susceptible B. resistant

All of the seven RAPD primers showed in both monomorphic and polymorphic bands with various number of fragments (Fig 2 and 3). Roslim (2001) noted that primer selection in RAPD analysis has influenced on the fragment polymorphism generated, since every primer has its specific annealing sites on the DNA template.

Table 1. Comparison between susceptible and resistant S. nodiflora vigor

\section{Parameters observed}

upper side colour of leaf

lower side colour of leaf

leaf positioning

leaf length $(\mathrm{cm})$

leaf width $(\mathrm{cm})$

leaf thickness $(\mu \mathrm{m})$

leaf area $\left(\mathrm{cm}^{2}\right)$

LAI

plant height $(\mathrm{cm})$ susceptible S. nodiflora

resistant S. nodiflora

dark green, glossy
bluish green, obtuse
sparse
$7.76 \pm 0.34$
$5.05 \pm 0.30$
$111.87 \pm 6.38$
$478.32 \pm 27.78$
$0.95 \pm 0,15$
$34.80 \pm 0.57$

lighter green, glossy

green, obtuse

solid

$8.76 \pm 0.69$

$5.33 \pm 0.44$

$83.00 \pm 8.06$

$553.58 \pm 57.84$

$1.22 \pm 0.13$

$27.40 \pm 1.52$ 
Different number of fragments are to some extent due to different allele frequencies in each locus. When the frequency of most common allele reaches 0.95 or more, the locus is said to be monomorphic, since the presence of the other rare allele can be neglected. Oppositely, when the frequency of most common allele is less than 0.95, it means that the other allele can also be found in the population and the locus is said to be polymorphic. The presence of certain fragments may increase heterozygosity indicating higher genetic diversity (Harris, 1994.

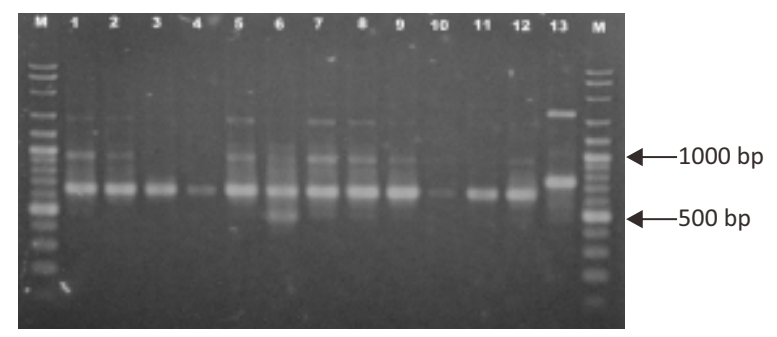

A

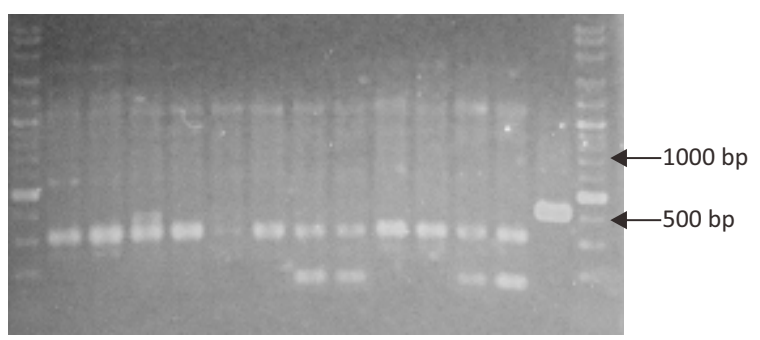

B

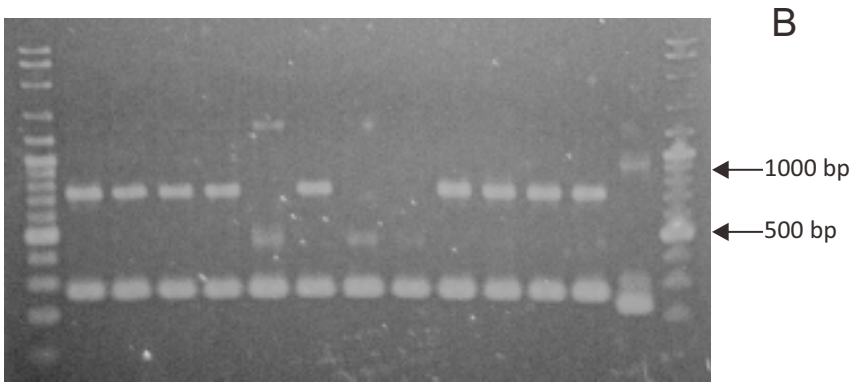

C

Figure 2. Band pattern of RAPD markers amplified with three different primers
A. OPA-7
B. OPA-8
C. OPA-11

Lane 1. marker

Lane 2-4. resistant S. nodiflora from Karangwangkal, Purwokerto

Lane 5-7. susceptible S. nodiflora from Karangwangkal, Purwokerto

Lane 8-9 susceptible S. nodiflora from Tanah Baru, Bogor

Lane 10-11. susceptible S. nodiflora from under tree steady stand, Cibinong, Bogor

Lane 12-13. susceptible S. nodiflora from Ecopark, Cibinong, Bogor

Lane 14. ground nut from Balitkabi, Malang

Lane 15. marker

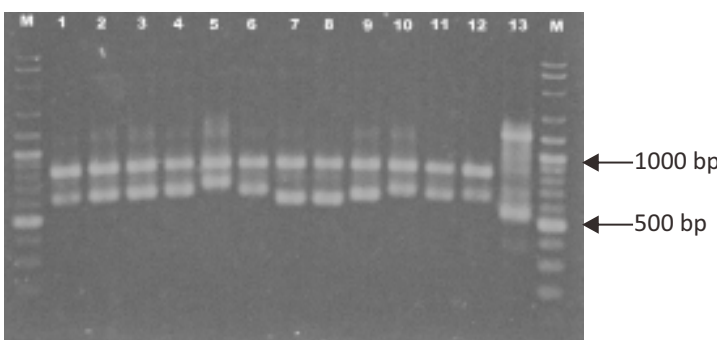

A

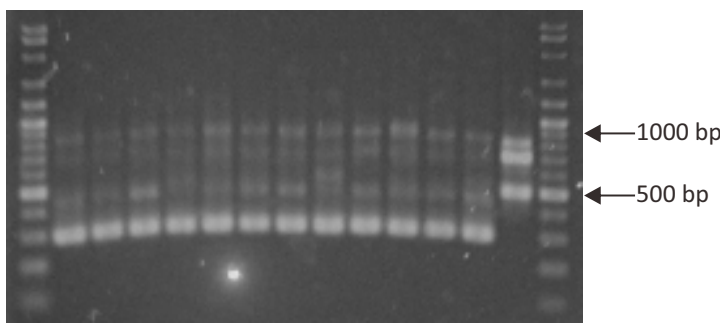

C

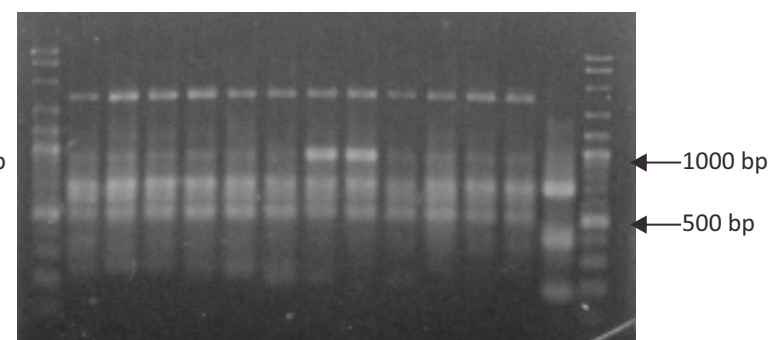

B

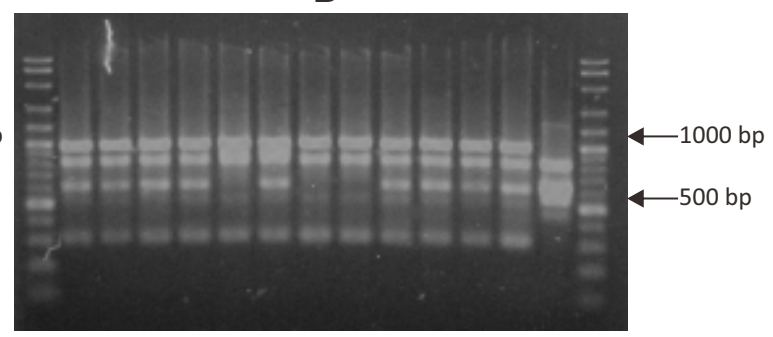

D

Figure 3. Band pattern of RAPD markers amplified with four different primers
A. OPB-6
B. OPB-7
C.OPB-8
D.OPB-10 
Lane 1. marker

Lane 2-4. resistant S. nodiflora from Karangwangkal, Purwokerto

Lane 5-7. susceptible S. nodiflora from Karangwangkal, Purwokerto

Lane 8-9 susceptible S. nodiflora from Tanah Baru, Bogor

Lane 10-11. susceptible $S$. nodiflora from under tree steady stand, Cibinong, Bogor

Lane 12-13. susceptible S. nodiflora from Ecopark, Cibinong, Bogor

Lane 14. ground nut from Balitkabi, Malang

Lane 15. Marker

Yuwono (2006) noted that a template DNA may not be successfully amplified by a primer because of no homologous site available between both. As well, the random primer used may anneal at two distant sites in the template causing the failure of DNA polymerase to amplify.

The amplified RAPD markers using seven selected primers were shown in Table 2. The DNA band intensity of individual primer is highly affected by primer binding site distribution in template DNA and the concentration and purity of template DNA containing polysaccharide and phenolic com-pounds. Primer competition for annealing sites in template DNA may lead to different number of amplified fragments (Roslim, 2001).

Polymorphism results from different positions of primer annealing at genomic DNA strand or different sequences among individuals. In addition, polymorphism can also be caused by substitution, deletion or insertion resulting in the loss of primer recognition sites (Salam, 1994).

It can be seen from Table 2 that polymorphism among individuals based on the amplified markers using seven selected primers exists. Polymorphism indicates genetic diversity of a species and its response to evolution process and predicts the existence of a species in the future (Solikhin, 2006).

The percentage of polymorphic bands obtained is sufficiently high ranging from 85.7 to $90.9 \%$. Two primers (OPB-7 and OPB-10), however, show low polymorphism, i.e. 66.7 and $40.0 \%$ respectively (Table 2 ). Poerba and Martanti (2008) noted that primer selection for RAPD analysis influences the band polymorphism produced due to specific annealing sites. Consequently, the polymorphic DNA bands resulting from individual primer show differences both in number and size.

Table 2. Polymorphism of RAPD markers amplified with seven selected primers

\begin{tabular}{lcccccc}
\hline primer & $\begin{array}{c}\text { number of } \\
\text { markers } \\
\text { amplified }\end{array}$ & $\begin{array}{c}\text { number of } \\
\text { bands per } \\
\text { individual }\end{array}$ & $\begin{array}{c}\text { number of } \\
\text { monomorphic } \\
\text { markers }\end{array}$ & $\begin{array}{c}\text { number of } \\
\text { polymorphic } \\
\text { markers }\end{array}$ & $\begin{array}{c}\text { size range } \\
(\mathrm{bp})\end{array}$ & $\begin{array}{c}\text { polymor- } \\
\text { phism } \\
(\%)\end{array}$ \\
OPA-7 & 8 & $1-8$ & 1 & 7 & $500-2200$ & 87.5 \\
\hline OPA-8 & 8 & $4-8$ & 1 & 7 & $200-1200$ & 87.5 \\
OPA-11 & 7 & $2-7$ & 1 & 6 & $250-1250$ & 85.7 \\
OPB-6 & 11 & $3-11$ & 1 & 10 & $400-2000$ & 90.9 \\
OPB-7 & 9 & $4-9$ & 3 & 6 & $200-1750$ & 66.7 \\
OPB-8 & 7 & $4-7$ & 1 & 6 & $350-900$ & 85.7 \\
OPB-10 & 4 & $4-5$ & 3 & 2 & $300-1350$ & 40.0 \\
\hline
\end{tabular}

Polymorphism exists both within susceptible S. nodiflora samples from Bogor and between these samples and that from Purwokerto, which is also shown by scatter plot diagram (Figure 4). Two samples of susceptible $S$. nodiflora from Purwokerto are present in quadrant II, while the other one lays on quadrant III. On the other hands, resistant $S$. nodiflora samples cluster in quadrant II, but they lay apart from the two sus ceptible samples, meaning that resistant and susceptible samples are genetically different from each other. Imron et al .(2000) noted that the level of genetic diversity determines genetic quality of a population. Lower genetic diversity may result in some deleterious traits, such as lower environmental adaptability including that against herbicide stress. 


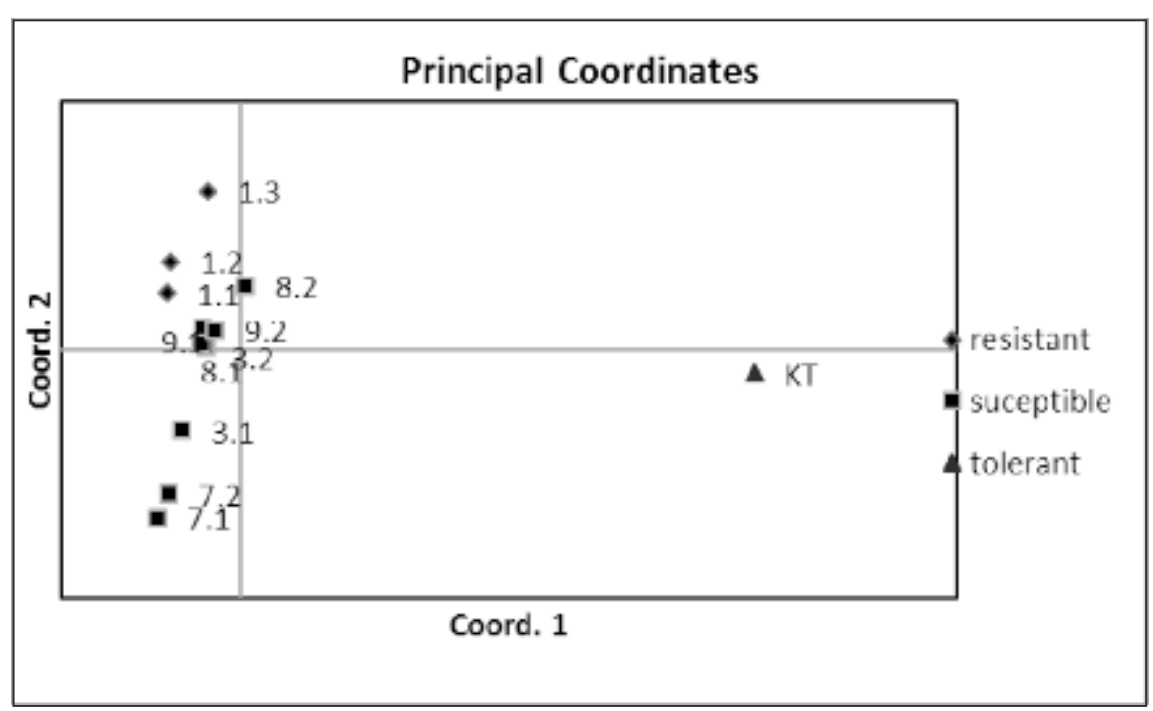

Figure 4. Scatter plot diagram of resistant and susceptible Synedrella. nodiflora

1.1 resistant S. nodiflora from Karangwangkal, Purwokerto

1.2 resistant $S$. nodiflora from Karangwangkal, Purwokerto

1.3 resistant $S$. nodiflora from Karangwangkal, Purwokerto

3.1 susceptible S. nodiflora from Karangwangkal, Purwokerto

3.2 susceptible S. nodiflora from Karangwangkal, Purwokerto

3.3 susceptible S. nodiflora from Karangwangkal, Purwokerto

7.1 susceptible S. nodiflora from Tanah Baru, Bogor

7.2 susceptible S. nodiflora from Tanah Baru, Bogor

8.1 susceptible S. nodiflora from under tree steady stand, Cibinong, Bogor

8.2 susceptible $S$. nodiflora from under tree steady stand, Cibinong, Bogor

9.1 susceptible S. nodiflora from Ecopark, Cibinong, Bogor

9.2 susceptible S. nodiflora from Ecopark, Cibinong, Bogor

KT ground nut from Balitkabi, Malang

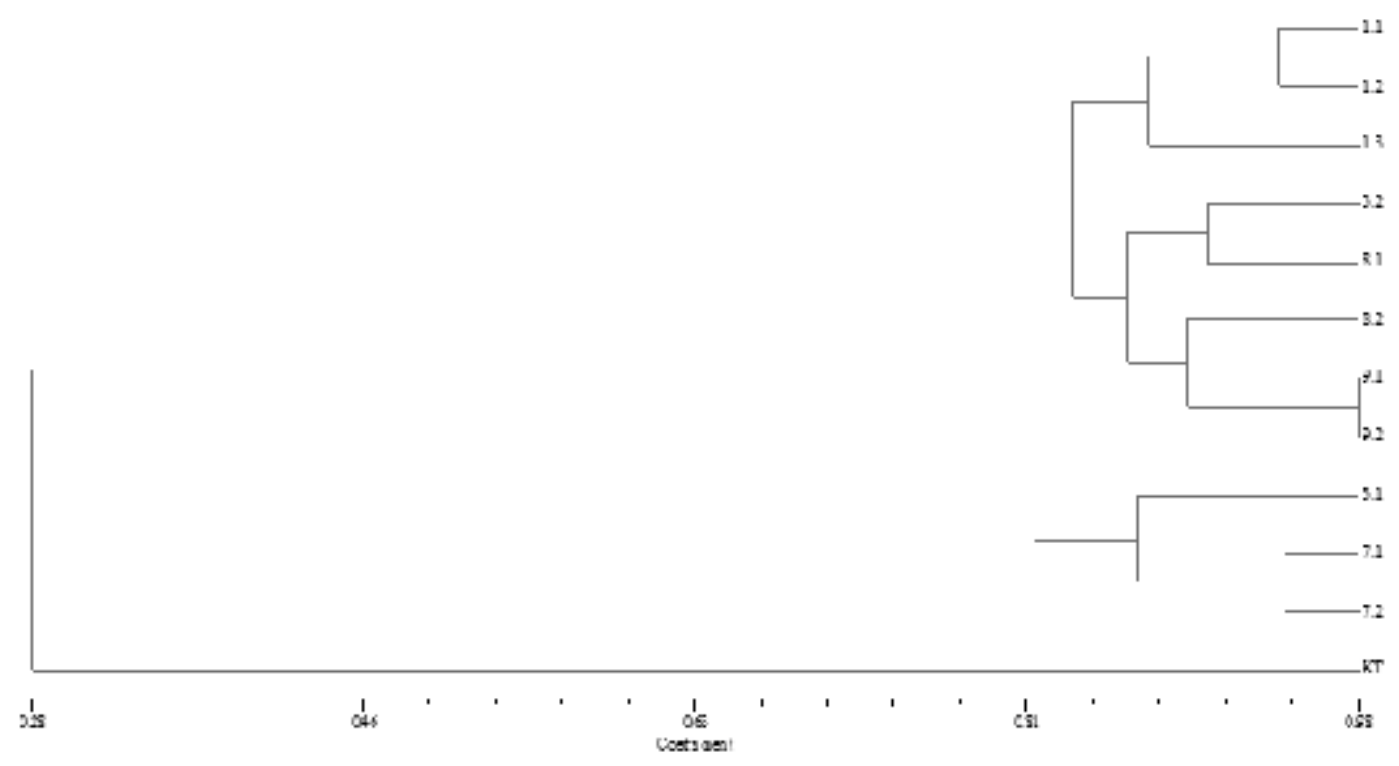

Figure 5. Dendrogram of resistant and susceptible Synedrella nodiflora 
1.1 resistant S. nodiflora from Karangwangkal, Purwokerto

1.2 resistant S. nodiflora from Karangwangkal, Purwokerto

1.3 resistant S. nodiflora from Karangwangkal, Purwokerto

3.1 susceptible S. nodiflora from Karangwangkal, Purwokerto

3.2 susceptible S. nodiflora from Karangwangkal, Purwokerto

3.3 susceptible S. nodiflora from Karangwangkal, Purwokerto

7.1 susceptible S. nodiflora from Tanah Baru, Bogor

7.2 susceptible S. nodiflora from Tanah Baru, Bogor

8.1 susceptible S. nodiflora from under tree steady stand, Cibinong, Bogor

8.2 susceptible S. nodiflora from under tree steady stand, Cibinong, Bogor

9.1 susceptible S. nodiflora from Ecopark, Cibinong, Bogor

9.2 susceptible S. nodiflora from Ecopark, Cibinong, Bogor

KT ground nut from Balitkabi, Malang (outgroup)

Table 3. Indeks similaritas antara sampel S. nodiflora resisten dan S. nodiflora rentan

\begin{tabular}{|c|c|c|c|c|c|c|c|c|c|c|c|c|}
\hline & 1.1 & 1.2 & 1.3 & 3.1 & 3.2 & 7.1 & 7.2 & 8.1 & 8.2 & 9.1 & 9.2 & KT \\
\hline 1.1 & 1.000 & & & & & & & & & & & \\
\hline 1.2 & 0.885 & 1.000 & & & & & & & & & & \\
\hline 1.3 & 0.724 & 0.821 & 1.000 & & & & & & & & & \\
\hline 3.1 & 0.656 & 0.688 & 0.667 & 1.000 & & & & & & & & \\
\hline 3.2 & 0.690 & 0.724 & 0.645 & 0.688 & 1.000 & & & & & & & \\
\hline 7.1 & 0.700 & 0.677 & 0.559 & 0.806 & 0.677 & 1.000 & & & & & & \\
\hline 7.2 & 0.667 & 0.700 & 0.576 & 0.719 & 0.645 & 0.893 & 1.000 & & & & & \\
\hline 8.1 & 0.667 & 0.759 & 0.677 & 0.774 & 0.821 & 0.710 & 0.677 & 1.000 & & & & \\
\hline 8.2 & 0.655 & 0.750 & 0.786 & 0.710 & 0.750 & 0.645 & 0.667 & 0.786 & 1.000 & & & \\
\hline 9.1 & 0.724 & 0.759 & 0.677 & 0.719 & 0.759 & 0.710 & 0.733 & 0.733 & 0.786 & 1.000 & & \\
\hline 9.2 & 0.700 & 0.733 & 0.710 & 0.750 & 0.733 & 0.688 & 0.710 & 0.767 & 0.821 & 0.963 & 1.000 & \\
\hline KT & 0.114 & 0.136 & 0.159 & 0.174 & 0.163 & 0.130 & 0.133 & 0.186 & 0.225 & 0.186 & 0.209 & 1.000 \\
\hline
\end{tabular}

Within the susceptible $S$. nodiflora samples, we can see that they have different distribution in quadrant III as illustrated in Figure 4. Even that from under tree steady stand, Cibinong, Bogor is found in quadrant 1 . As comparison, tolerant Arachis hypogaea sample lays apart in quadrant IV.

The lowest similarity index is observed between sample 7.1 (suscep- tible $S$. nodiflora from Tanah Baru) and sample 3.1 (susceptible $S$. nodiflora from Karangwangkal, Purwokerto), while the highest similarity index is found between sample 9.1 and 9.2, both of which are from Ecopark (Table 3). This means that both samples from Ecopark are very similar to each other. On the other hands, similarity index between sample 7.1 and 7.2 is relatively high, i.e. 0,893 . Sufficiently high similarity indices are observed among resistant S. nodiflora, i.e 0.885 between sample 1.1 and 1.2 , and 0.821 between sample 1.2 and 1.3 , meaning that very high similarity is observed among samples 1.1,
1.2 , and 1.3 , which separate sufficiently from susceptible $S$. nodiflora. Similarity index between sample 3.1 and 3.2 is only 0.545 and that between sample 3.2 and 3.3 is only 0.688 , meaning that the three susceptible $S$. nodiflora samples from Karangwangkal are relatively diverse. The scatter plot data corresponds to dendogram analysis illustrated in Figure 5. It is shown that resistant and susceptible $S$. nodiflora is separated in two different clusters with a similarity coefficient of 0.68 and ground nut from Balikabi, Malang as outgroup sample. Higher variation is, however, observed within the three susceptible samples from Purwokerto, since one of them is present in the same cluster as that for the resistant samples.

\section{Conclusion}

Based on the RAPD markers used in this study, it can be concluded that genetic distance between susceptible and resistant S. nodiflora against fomesafen is higher than 
that within susceptible samples supporting our previous morphological and protein data, although genetic variation among susceptible individuals seems to be significantly high.

\section{Acknowledgements}

Gratefulness is addressed to Tantri Swandari and Santi Aji Mawarni for their valuable assistance in the laboratory work and data anaysis.

\section{References}

Doyle J J , Doyle J L (1990) Isolation of plant DNA from fresh tissue. Focus 12(1):13-15.

Dwiati M, Susanto A.H (2015) Plastidal and mitochondrial protoporphyri-nogen oxidase profiles in Synedrella nodiflora resistant and susceptible to herbicide of Fomesafen. ICPD Seminar

Harris H (1994) Dasar-dasar Genetika. Gadjah Mada University Press. Yogyakarta.

Imron O, Arifin Z, Subagyo ( 2000) Karakterisasi truss morfometrik pada ikan mas galur Malaya, Rajadanu, Wildan dan Sutisna. Prosiding Seminar Hasil Perikanan 1999/2000. Puslit-bang Eksplorasi Laut dan
Perikanan. Departemen Eksplo-rasi Laut dan Perikanan, Jakarta.

Poerba YS, Martanti D (2008) Keanekaragaman genetik berdasarkan marka Random Amplified Polymorphic DNA pada Amorphophallus muelleri Blume di Jawa. Biodiversitas 9:245-249.

Roslim DI (2001) Kemiripan genetik tiga populasi kelapa dari tiga pulau dengan penanda RAPD. [Tesis]. Program Pascasarjana IPB. Bogor.[Indonesia]

Runtunuwu SD, Hartana A, Suharsono (1999) Penanda RAPD untuk Penyakit Phytophtora Gugur Buah Kelapa. Prosiding Semi-nar Hasil Penelitian Bidang IImu Hayat. PAU IImu Hayat IPB. Bogor, 16 September 1999. [Indonesia]

Salam AMS (1994) Keanekaragaman genetik. Andi offset. Yogya-karta.

Solikhin DD (2006) Teknik elektroforesis. Makalah Pelatihan Teknik Diagnostik Molekuler, PSHB. 10-23.

Tartarini S (1995) RAPD markers linked to the Vf gene scab resistance in apple tag. Theoretical and Applied Genetics 92(7) : 803-810.

Yuwono T (2006) Teori dan aplikasi Polymerase Chain Reaction Penerbit Andi. Yogyakarta. 